\title{
A potential phosphorous fertilizer for organic farming: recovery of phosphorous resources in the course of bioenergy production through anaerobic digestion of aquatic macrophytes
}

Nele Stabenau ${ }^{1,2}$, Andreas Zehnsdorf $^{3 *}$, Helmut Rönicke ${ }^{4}$, Harald Wedwitschka ${ }^{1}$, Lucie Moeller ${ }^{3}$, Bachar Ibrahim ${ }^{5}$ and Walter Stinner ${ }^{1}$

\begin{abstract}
Background: A major problem with farming systems is the deficiencies in phosphorus (P) due to fixation in soils, erosion and run-off, and exports of herbal and animal products. P resources for the compensation of these losses will sooner or later be depleted. For this reason, innovative ideas for phosphorus recycling are highly relevant. The P excess from farming systems mostly ends up in surface waters, leads to eutrophication, and promotes the growth of aquatic plants. Particularly invasive neophytes such as western waterweed (Elodea nuttallii) can rapidly generate high levels of biomass in waters with good nutrient supply and bind relevant amounts of phosphorus.

Methods: In the renatured open-pit mine Goitzsche (Saxony-Anhalt, Germany), biomass from E. nuttallii was harvested (2005-2008) and the biomass dry matter and the P concentration were determined. The phosphorus recovery potential from this plant biomass was calculated by extrapolation based on the phosphorus analyses and the area potentially populated by E. nuttallii. One analysis of E. nuttallii was conducted to evaluate the content of potentially toxic elements (PTEs).

Results: The results showed that with 0.5 to $6.3 \mathrm{~kg}$ P/Mg of total solid (dry matter), E. nuttallii could have a high potential to recycle phosphorus, e.g., by anaerobic digestion and digestate fertilization. Lake Goitzsche offered an annual recovery potential from 0.5 to $1.7 \mathrm{Mg}$ phosphorus in the investigation period. This could meet the needs of 114-ha organic farming land based on a $7 \mathrm{~kg} /($ ha* year) regional phosphorus deficit.

The digestate of $E$. nuttallii is very well suited as a fertilizer due to its high phosphorus concentration. The concentrations of PTEs in the current digestate (related to an individual case) are sufficient for legal admission in Germany. In this study, nickel was above the threshold values for Germany. The elevated nickel levels in the Elodea biomass correspond to the geogenic high nickel concentrations in the sediment of this lake.

Conclusions: Aquatic macrophytes have a significant potential for recovering phosphorus from waters and sediments of relevant phosphorus concentrations. Further studies of surface water zones, particularly with regard to the aquatic plant biomass and phosphorus concentration of sediments, are needed to assess future exploration.
\end{abstract}

Keywords: Phosphorus, P resources, P recycling, Aquatic macrophytes, Elodea nuttallii, Organic farming, Digestate, Anaerobic digestion, Biogas

\footnotetext{
* Correspondence: andreas.zehnsdorf@ufz.de

${ }^{3}$ Department of Environmental Biotechnology, Helmholtz Centre for

Environmental Research, Permoserstrasse 15, 04318 Leipzig, Germany

Full list of author information is available at the end of the article
} 


\section{Background}

Phosphorus is a non-substitutable plant nutrient and therefore essential for agriculture and human consumption. Besides the fixation of phosphorus in soils and losses by erosion and run-off, the main interruption of the phosphorus cycle is caused by the export of herbal and animal products from agricultural production $[1,2]$. The occurring deficiencies may be compensated by using organic or mineral phosphorus (P) fertilizers. However, mineral $\mathrm{P}$ is a scarce resource. Estimates for the range of $\mathrm{P}$ reserves differ rather to some extent because of unknown development parameters, such as an increase in food production and efficiency enhancement of fertilizer use [3-7]. Sooner or later, mineral $P$ resources will be depleted. Especially in organic farming, the compensation of $\mathrm{P}$ deficiencies is limited due to the amount of available mineral $\mathrm{P}$ fertilizers permitted for use according to the Commission Regulation (EC) No. 889/2008, German fertilizer ordinance (Annex 2, Table 1.4 DüMV) and standards applied by the organic associations (e.g., Demeter, Bioland, Naturland). And thus, $\mathrm{P}$ recycling is necessary for agriculture and is of particular interest for organic farming.

A potential source of $\mathrm{P}$ may be the biomass of aquatic plants that must be harvested for water maintenance. In particular, aquatic neophytes such as the two waterweed species (Elodea nuttallii and Elodea canadensis) play an important role as they are able to produce a lot of biomass in a short time under favorable conditions.

E. nuttallii as an invasive aquatic macrophyte species of North American origin was observed for the first time in 1939 in Europe [8-10]. E. nuttallii grows submerged in slow-running and standing waters and often breeds dense stands there [9-11]. In Europe, male and female plants rarely occur together in the same population, and regeneration is predominantly vegetative [12]. New plants develop from shoot fragments, which accumulate on the ground at the end of a growing period $[9,11]$. Therefore, the distribution is effected by means of flow paths, shipping, and water birds [9].

Generally, a mass growing of aquatic macrophytes could result in ecological and economic problems. Apart from the disability of leisure activities and boat traffic, fluently transferred aquatic plants are able to block hydraulic structures especially in autumn. Furthermore, the decomposition of aquatic plants at the end of a growth period results in significant oxygen consumption and release of nutrients. This leads to an accumulation of fermentation end products in the metabolism of anaerobic bacteria which are toxic for many aquatic organisms $[13,14]$. Hence, their population in German waters needs to be reduced, e.g., by mechanical removal [14].

According to a number of estimates from 2008, the cost for the removal of weeds from unnatural running waters (constructed waterways) in Germany amounted to about 100 million euros per year [15]. When considering the increasing spread of neophytes in non-floating waters, these costs could be higher. According to estimates, only the cost for disposal of the biomass amounts to about 20 million euros [16].

The necessity of harvesting the aquatic plant biomass and the associated costs requires a possibility of use instead of disposing of the biomass as a waste.

Discontinuous anaerobic digestion trials were conducted to evaluate the suitability of aquatic plant biomass as a substrate for biogas production. The results indicate that aquatic macrophytes, such as E. nuttallii, have appropriate substrate characteristics and allow considerable biogas yields comparable to hay to be achieved [17]. During anaerobic digestion, methane $\left(\mathrm{CH}_{4}\right)$ and carbon dioxide $\left(\mathrm{CO}_{2}\right)$ are formed, but nutrients like $\mathrm{P}$ remain in the digestate $[18,19]$.

With a share of 1.0 to $1.6 \mathrm{~kg} \mathrm{P} / \mathrm{Mg}$ of total solid (according to the results of previous investigations), E. nuttallii has a potential as a phosphorus pool, being suitable as a substrate for the extraction of $\mathrm{P}$ resources by means of regular harvesting and anaerobic digestion [14].

The aim of the study was to estimate the potential of $\mathrm{P}$ recovery through harvest and anaerobic digestion of aquatic macrophytes (especially $E$. nuttallii) with the objective to use the digestate as a fertilizer in agriculture within the legal limits for heavy metal concentrations.

\section{Methods}

\section{Study site and sampling}

The study area was Lake Goitzsche $\left(51^{\circ} 37^{\prime} 35^{\prime \prime} \mathrm{N}, 12^{\circ}\right.$ $21^{\prime} 49^{\prime \prime}$ E), located in a renatured mining area near Bitterfeld (Saxony-Anhalt) in central Germany. As a result of a flood in the summer of 2002, the nutrient-rich water of the river Mulde provoked a short-term eutrophication of the lake. Due to a high number of Pbinding cations (especially iron), phosphorus was rapidly fixed in lake sediments [20]. Consequently, the nutrient content of water bodies decreased to a nutrient-poor (oligotrophic) range [20]. Currently, the water conditions of the lake are oligotrophic to mesotrophic (middle nutrient status) and chemically neutral ( $\mathrm{pH} 7$ ) [20]. The lake surface is 1331 ha $\left(13.31 \mathrm{~km}^{2}\right)$ at $75 \mathrm{~m}$ above sea level. Lake Goitzsche has a maximum depth of $49 \mathrm{~m}$ and holds a volume of 212.8 million $\mathrm{m}^{3}$ water, which makes it one of the largest lakes in central Germany [20-22]. The area of the littoral, where sunlight penetrates all the way to the sediment and allows aquatic plants to grow, is 399 ha [23].

The invasive macrophyte species E. nuttallii ranked, beside Characeen, as a dominant species in Lake Goitzsche in 2005, 2006, 2007, and 2008. The first of the monthly sampling campaigns within a year was between 
May and June and the last between September and December.

Over the investigation period, fresh matter of $E$. nuttallii from Lake Goitzsche was intensively examined in the sub-basins Pouch, Bärenhof, Niemegk, Mühlbeck, and Döbern (Fig. 1) [20, 23-25]. Since sprouts of E. nuttallii died off in winter and sprouted again from the residual root system of the sediment in the next spring, the samples from the whole vegetation period could be used for an annual balance of E. nuttallii biomass. Due to the significant dominance of E. nuttallii over Characeen, only the data of E. nuttallii were used for the calculation in this study.

The sub-basins were marked by fixed white ropes along a line on the ground to facilitate rediscovery of the same areas over years. For sampling, two divers used weight belts and a depth gauge to determine the desired depth. At depths of $1,2,3,4$, and $5 \mathrm{~m}$, a steel frame of $1-\mathrm{m}^{2}$ size was placed. From this steel frame, the total biomass of macrophytes was harvested (without the root system, by cutting near to ground level) and collected in a mesh bag. Following the complete harvest of $1 \mathrm{~m}^{2}$, the mesh bag was brought up to the accompanying boat and transferred to a plastic bag.

During every dive, all depths were examined with regard to new growth. Only sporadic developments of macrophytes in some sub-basins were not included in the harvest. In the case of repeated sampling, the steel frame was positioned on non-harvested areas at appropriate depths.

For analyses of potential toxic elements (PTEs), Lake Goitzsche was sampled on the 23rd of June 2011. This sampling was made in the Mühlbeck subbasin near the peninsula Pouch $\left(51^{\circ} 37^{\prime} 43.2^{\prime \prime} \mathrm{N}\right.$, $\left.012^{\circ} 22^{\prime} 50.9^{\prime \prime} \mathrm{E}\right)$, not far from the shore and at a 0 . 5 -m water depth.

\section{Analysis}

The plants were weighed at the shore (fresh matter) and transported to the laboratory, where they were flushed with water to remove sediment, as well as cut and airdried. Grinding was carried out using an Ultra Centrifugal Mill of type Retsch ZM1 using a 0.25-mm titanium sieve insert. The fresh samples of $E$. nuttallii were weighed and dried at $105{ }^{\circ} \mathrm{C}$ to a constant weight to determine their total solids (TS) following DIN 12880. An aliquot of the dried sample was milled and heated to $550{ }^{\circ} \mathrm{C}$ in a muffle furnace to determine the content of volatile solids (VS) according to DIN 12879. According to Weißbach and Strubelt, the TS and VS contents of all samples were corrected for the volatile organic compounds that were lost during oven drying, i.e., lactic acid, volatile short-chain fatty acids (C2-C7), methanol, ethanol, and propanol [26].

The determination of the phosphorus concentration was carried out by spectrophotometric detection according to DIN 38405-D11: $0.5 \mathrm{~g}$ of dried (at $105{ }^{\circ} \mathrm{C}$ ) and milled plant material was eluted with a mixture of $5 \mathrm{ml}$ $\mathrm{HNO}_{3}$ and $0.5 \mathrm{ml} \mathrm{H}_{2} \mathrm{O}_{2}$ at $260{ }^{\circ} \mathrm{C}$, filled with $50-\mathrm{ml}$ water and analyzed by means of inductively coupled plasma-optical emission spectrometry (ICP-OES).

The minimum, maximum, and mean values of phosphorus concentrations for each year were determined, whereby all depths of the different dives, including the unvegetated depths (zero gram biomass), became involved (except minimum determination).

For the ICP-MS analysis of PTEs (As, Pb, Cd, Ni, Cr, $\mathrm{Cu}$ ) using samples from an investigation in 2011, $0.5 \mathrm{~g}$

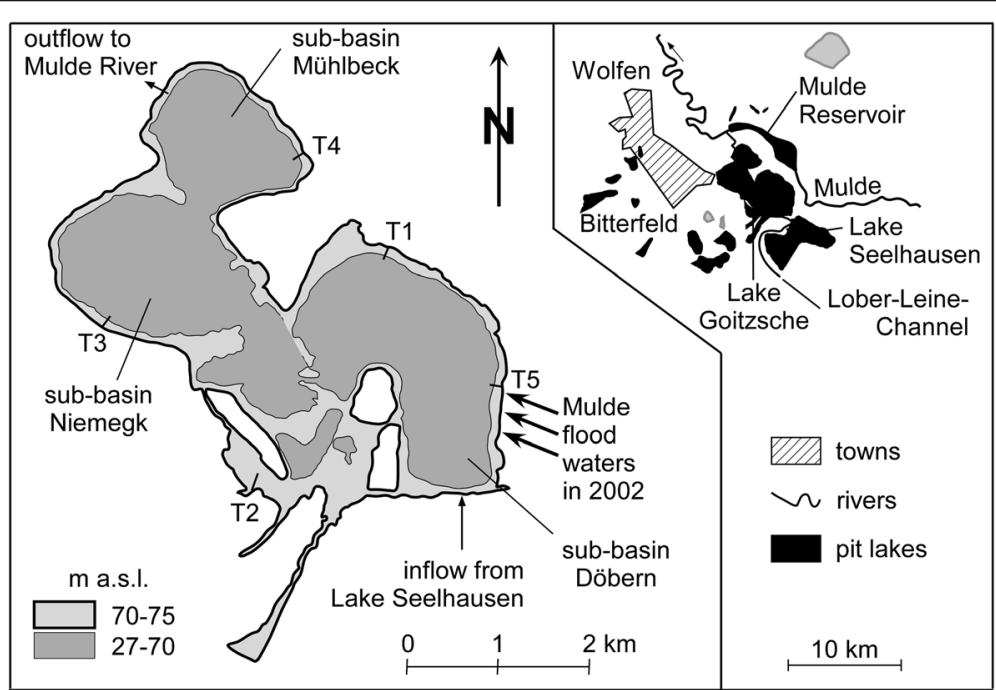

Fig. 1 Overview of the investigated area of Lake Goitzsche. Location of Lake Goitzsche and sub-basins Pouch (T1), Bärenhof (T2), Niemegk (T3), Mühlbeck (T4), and Döbern (T5) in the littoral area populated by E. nuttallii (area 70-75 m above mean sea level). Adapted from Rönicke et al. [24] 
of milled plant material was eluted with a mixture of $4 \mathrm{ml} \mathrm{HNO}_{3}(65 \%)$ and $0.5 \mathrm{ml} \mathrm{H}_{2} \mathrm{O}_{2}$ (30\%) for $30 \mathrm{~min}$ at $10 \mathrm{MPa}$ and $250{ }^{\circ} \mathrm{C}$. For the pulping processes, an ultraCLAVE III Microwave Digestor (MLS GmbH) was employed. The resulting solutions were filtrated by means of a cellulose-acetate membrane (Sartorius) of 0 . $45-\mu \mathrm{m}$ pore size and filled with deionized water (MilliQElement; Millipore) to $50 \mathrm{ml}$, ensuring that an analysis would be carried out using a PerkinElmer SCIEX Elan DRC-e inductively coupled plasma mass spectrometery (ICP-MS). Additionally, the P concentration was determined by means of an ICP-MS and the zinc (PTE) concentration by means of inductively coupled plasmaoptical emission spectrometry (ICP-OES).

\section{Anaerobic digestion batch tests}

The potential of the harvested macrophytes to produce methane by anaerobic digestion was measured in biochemical methane potential (BMP) tests on a laboratory scale, following the standardized method protocol VDI 4630 published by the Association of German Engineers [27]. Eudiometers (Neubert Glas GbR, Geschwenda, Germany) were used as gas production measurement devices to determine the specific methane yield of the $E$. nuttallii plant material. The samples consisted of $500 \mathrm{~g}$ of inoculum and approximately $2.5 \mathrm{~g}$ of volatile solids (VS) of the substrate, each in three replications. The inoculum was derived from the DBFZ research biogas plant, which was operated at $37^{\circ} \mathrm{C}$ using corn silage and cattle manure as the feedstock materials. Digestate from the primary digester was sieved $(5 \mathrm{~mm})$ and degassed at room temperature for 5 days to decrease the residual biogas generation. The inoculum to substrate rate (ISR) was approximately $2: 1$. In addition to the sample materials, a blank sample containing solely inoculum was tested to determine the endogenous methane yield in order to subtract it from the sample methane production. Microcrystalline cellulose was used as a reference substrate, to monitor the inoculum performance. The headspace of the sample flasks was flushed with nitrogen prior incubation. Headspace correction was carried out as described in the method description VDI 4630 [27]. The test was operated under mesophilic conditions $\left(38^{\circ} \mathrm{C}\right)$, while stirring once a day. Gas composition measurement was completed using a land fill gas monitor (GA2000, Ansyco, Karlsruhe, Germany). The BMP test concluded when the daily biogas production was below $1 \%$ of the total biogas production over a period of five consecutive days. The specific methane yield was calculated under standard conditions $273.15 \mathrm{~K}$ and $1.01325 \times 10^{5} \mathrm{~Pa}$.

\section{The calculation of the phosphorus recovery potential}

The total $\mathrm{P}$ recovery potential $\left(\mathrm{TP}_{\mathrm{pot}}\right)$ was calculated by multiplying the total solid of $E$. nuttallii produced in the littoral zone of Lake Goitzsche $\left(\mathrm{TS}_{\text {littoral }}\right)$ by the average $\mathrm{P}$ concentration $\left(\mathrm{TP}_{\text {mean }}\right)$.

For the assessment of the fulfillment of phosphorus demand in organic farming, a study by Harzer [28] was taken as a basis. This study presented phosphorus accounting in nine organic farms between 2003 and 2004. The investigated organic farms were located in four different agricultural regions in Saxony-Anhalt and classified by their yield in the following groups: three cash crop farms with low yield (soil quality (Ackerzahl) $<40$ ), three mixed farms with middle yield (soil quality (Ackerzahl) 40-60), and three crash crop farms with high yield (soil quality (Ackerzahl) > 80). One farm was classified as a cash crop farm due to the low stocking density $(<0$. 2 livestock unit). The accounting was made by the computer-aided balance model REPRO. One of the farms showed particularly high $\mathrm{P}$ surplus $(26 \mathrm{~kg} \mathrm{P} /$ (ha*year)) due to imported manure. The added P quantity of that one of the investigated farms was equivalent to three times the amount that would be expected from manure under complete feeding of all growths. As this is a non-regular condition for organic farming, this farm was not included in the calculation of the mean P deficit. The balance results showed $P$ deficits between -14 and $-1 \mathrm{~kg} /$ (ha*year) [27], which resulted in a mean phosphorus deficit of $7 \mathrm{~kg} \mathrm{P/(ha*year).}$

\section{Estimation of the concentrations of $P$ and harmful substances in digestates}

During anaerobic digestion, elements not converted to gas will increase in concentration due to the mass reduction by decomposition of organic matter [29]. As the water remains undegraded, the enrichment is higher in the total solids (TS). This change is important for the evaluation of the suitability as a fertilizer under the conditions of German law (German fertilizer ordinance, Annex 2, Table 1.4). There are limit values of heavy metals in fertilizers, related to the concentration in the DM. It is possible to determine the change by a specific enrichment factor (EF). The mass of biogas corresponds to the mass reduction of the substrate. Biogas contains (after gas cleaning, separation of $\mathrm{NH}_{3}$ and $\mathrm{H}_{2} \mathrm{~S}$ contents and its return into the digestate) only $\mathrm{C}, \mathrm{H}$, and $\mathrm{O}$, as the other elements became enriched. Thus, the enrichment factor of the TS resulted from the relation between the initial total solid and the mass of the total solid of the digestate. As a basis for the calculation, the corrected mean values (Weißbach correction) of total solid $\left(\mathrm{TS}_{\%}\right)$, volatile solids $\left(\mathrm{VS}_{\%}\right)$, the net average of specific gas production (q), and the mean mass fraction of methane in biogas $\left(\mathrm{w}_{\mathrm{CH} 4}\right)$ (results of the batch tests) were used. On this data basis, a mass calculation of the total solid $\left(\mathrm{m}_{\mathrm{TS}}\right)$, volatile solids $\left(\mathrm{m}_{\mathrm{VS}}\right)$, ash $\left(\mathrm{m}_{\mathrm{A}}\right)$, and water 
$\left(\mathrm{m}_{\mathrm{H} 2 \mathrm{O}}\right)$ was carried out for a chosen value of fresh matter $(\mathrm{FM}=1 \mathrm{~g})$.

\section{Results}

In general, the highest density of plant cover was determined during autumn. The results showed a variable, planar occurrence of $E$. nuttallii. The amount of fresh matter harvested per square meter varied between a few grams and several kilograms. On average, for all depths and locations, from 50 to $220 \mathrm{Mg}$ of total solid could be harvested per square kilometer and year (Table 1), which corresponded to yields of 0.5 to $2.2 \mathrm{Mg} / \mathrm{ha}$. This is a modest amount of total solid as compared with agricultural land, but if the harvesting has an additional purpose such as cleaning the water, this amount of plant material might be a valuable benefit.

The mean total $\mathrm{P}$ concentration $\left(\mathrm{TP}_{\text {mean }}\right)$ varied from $1.9 \mathrm{~kg} \mathrm{P} / \mathrm{Mg}$ TS $(2006,2007)$ to $2.4 \mathrm{~kg} \mathrm{P} / \mathrm{Mg}$ TS (2005) (Table 1).

For estimating the phosphorus concentration change during anaerobic digestion, the enrichment factor was determined, as described above. The results of the batch tests as well as the results of the mass calculation, used as a basis, are presented in Table 2. As the initial TSs before anaerobic digestion of 0.073 and $0.016 \mathrm{~g}$ were converted to biogas, an enrichment factor of 1.28 was achieved.

The phosphorus concentration in the digestate was determined using an enrichment factor $(E F=1.28)$. The results are presented in Table 3.

The potential toxic elements (PTE) concentrations in the digestate based on the dataset of 2011 were also calculated using the enrichment factor and compared with the threshold values in fertilizers according to the German fertilizer ordinance (Annex 2, Table 1.4 DüMV) (Table 4).

Table 1 Results of the projection of the phosphorus recovery potential from the years 2005 to 2008

\begin{tabular}{llllll}
\hline Year & & 2005 & 2006 & 2007 & 2008 \\
\hline $\mathrm{TS}_{\text {mean }}$ & {$\left[\mathrm{Mg} \mathrm{TS} / \mathrm{km}^{2}\right]$} & 49.6 & 60.7 & 219.8 & 70.0 \\
$\mathrm{TS}_{\text {min value }}$ & {$\left[\mathrm{Mg} \mathrm{TS} / \mathrm{km}^{2}\right]$} & 0.5 & 17 & 8 & 0.2 \\
$\mathrm{TS}_{\text {max value }}$ & {$\left[\mathrm{Mg} \mathrm{TS} / \mathrm{km}^{2}\right]$} & 313 & 283 & 1108 & 577 \\
$\mathrm{TS}_{\text {littoral }}$ & {$[\mathrm{Mg} \mathrm{TS}]$} & 197.8 & 242.2 & 877.2 & 279.1 \\
$\mathrm{TP}_{\text {mean }}$ & {$[\mathrm{kg} \mathrm{P} / \mathrm{Mg} \mathrm{TS}]$} & 2.4 & 1.9 & 1.9 & 2.1 \\
$\mathrm{TP}_{\text {min value }}$ & {$[\mathrm{kg} \mathrm{P} / \mathrm{Mg} \mathrm{TS}]$} & 1.2 & 0.9 & 0.5 & 0.5 \\
$\mathrm{TP}_{\text {max value }}$ & {$[\mathrm{kg} \mathrm{P} / \mathrm{Mg} \mathrm{TS}]$} & 6.3 & 4.8 & 4.9 & 4.1 \\
$\mathrm{TP}_{\text {pot }}$ & {$[\mathrm{kg}]$} & 474.8 & 460.1 & 1666.7 & 586.1 \\
& {$[\mathrm{Mg}]$} & 0.47 & 0.46 & 1.67 & 0.59
\end{tabular}

Calculation using non-rounded values, reference: Helmholtz-Centre for Environmental Research - UFZ. Mean value of the total solid of E. nuttallii ( $\mathrm{TS}_{\text {mean }}$ ); minimum and maximum value of the total solid of $E$. nuttallii excluding zero values $\left(\mathrm{TS}_{\min \text { value, }} \mathrm{TS}_{\max \text { value }}\right)$; total solid of $E$. nuttallii of total littoral area ( $\left.\mathrm{TS}_{\text {littoral }}\right)$; mean, minimum, and maximum value of total $\mathrm{P}$ concentration in $E$. nuttallii $\left(\mathrm{TP}_{\text {mean }}, \mathrm{TP}_{\min }\right.$ value, $\left.\mathrm{TP}_{\text {max value }}\right)$; total $\mathrm{P}$ recovery potential $\left(\mathrm{TP}_{\text {pot }}\right)$
The results of the determination of the total phosphorus recovery potential $\left(\mathrm{TP}_{\text {pot }}\right)$ in kilograms (Table 1$)$ were taken as a basis for the fulfillment of phosphorus demand by $E$. nuttallii digestate from Lake Goitzsche. Referring to the mean total phosphorus recovery potential $\left(\mathrm{TP}_{\mathrm{pot}, \text { mean }}\right)$ amounting to $796.9 \mathrm{~kg}$, the average deficit of the examined ecofarms of $7 \mathrm{~kg} \mathrm{P}$ (ha*year) could be covered for about 114 ha (Table 5). Thereby, the relationship between the littoral area (399 ha of 1331 ha total lake area) and the area of fulfillment of demand is on an annual average of 5 : $1,6: 1$, and $5: 1$ in 2005,2006 , and 2008, respectively. The most closely related at an average of 2:1 was achieved in a year of mass development, in 2007. The results of the (rounded) ratio calculation, also related to the total lake area, are given in Table 5. Detailed information about data base, calculations and extrapolation are given in the Additional file 1.

\section{Discussion}

A number of studies demonstrated that sediments were the main source of nutrients for rooted aquatic vascular plants in nutrient-poor lakes [30,31]. An extensive analysis of phosphorus concentrations in $E$. nuttallii biomass and water bodies took place in 2004. The phosphorus content in E. nuttallii biomass exceeded the phosphorus content in pelagic zones by far [23]. Consequently, a predominant nutrient uptake from the sediment, which could be supported by laboratory investigations, was assumed [23]. To achieve high growth rates, E. nuttallii stock relies on sufficient light [24]. Excavations between the late summer of 2004 and the spring of 2005 at the shore range had therefore resulted in lower growth in 2005 compared to the previous years. Hence, dredging between the late summer of 2004 and the spring of 2005 in the shore range could have led to lower growth in 2005 compared to the previous years. As influencing factors for the phosphorus content, fluctuations of limnophysical factors, such as light offering, temperature, and wind-related turbulences, came into account [25, 30, 32].

In order to assess the fertilizer usability of $E$. nuttallii digestate, the potential $\mathrm{P}$ concentrations in the digestate, estimated by using an enrichment factor, were converted from the elementary form to the oxide form $\mathrm{P}_{2} \mathrm{O}_{5}$ by a conversion factor of 2.2914 [33] (Table 6) and compared with different organic fertilizers.

It is apparent that the phosphorus content in the digestate of $E$. nuttallii is relatively high. Compared to the given organic fertilizer of plant origin, the $\mathrm{P}$ concentration in E. nuttallii digestate with 5.5 to $7.1 \mathrm{~kg} \mathrm{P}_{2} \mathrm{O}_{5} /$ $\mathrm{Mg}$ TS is significantly higher than the highest concentration in biowaste compost $\left(3.2 \mathrm{~kg} \mathrm{P}_{2} \mathrm{O}_{5} / \mathrm{Mg} \mathrm{TS}\right)$ [34]. Regarding the organic fertilizer of animal origin, the $\mathrm{P}$ concentrations of $E$. nuttallii digestates were slightly below the phosphorus concentrations of chicken manure/feces (7.5 kg $\left.\mathrm{P}_{2} \mathrm{O}_{5} / \mathrm{Mg} \mathrm{TS}\right)$ [33], but clearly differed 
Table 2 Results of batch tests and mass calculations

\begin{tabular}{|c|c|c|c|c|c|c|c|c|c|}
\hline & FM & $\mathrm{TS}_{\%}$ & $\mathrm{~m}_{\mathrm{TS}}$ & $\mathrm{VS}_{\%}$ & $m_{v s}$ & $m_{A}$ & $\mathrm{~m}_{\mathrm{H} 2 \mathrm{O}}$ & $\mathrm{W}_{\mathrm{CH} 4}$ & q \\
\hline Unit & [g] & {$\left[\% \%_{F M}\right]$} & [g] & {$\left[\%_{\mathrm{TS}}\right]$} & [g] & [g] & [g] & [\%] & {$\left[\left.\mathrm{m}\right|_{\mathrm{N}} / \mathrm{g}_{\mathrm{oDM}}\right]$} \\
\hline E. nuttallii & 1 & 7.3 & 0.073 & 66.62 & 0.049 & 0.024 & 0.927 & 58.0 & 257.5 \\
\hline
\end{tabular}

Reference: German Biomass Research Centre (DBFZ). Value of fresh matter (FM), percentage of total solid (TS $\%$ ), mass of the total solid ( $\left.\mathrm{m}_{\mathrm{TS}}\right)$, percentage of volatile solids $\left(\mathrm{VS}_{\%}\right)$, mass of volatile solids $\left(\mathrm{m}_{\mathrm{Vs}}\right)$, mass of ash $\left(\mathrm{m}_{\mathrm{A}}\right)$, mass of water $\left(\mathrm{m}_{\mathrm{H} 2 \mathrm{O}}\right)$, mean mass fraction of methane in biogas $\left(\mathrm{w}_{\mathrm{CH} 4}\right)$, corrected $($ Weißbach) net average of specific gas production $(q)$

from pig manure (1.6 $\left.\mathrm{kg} \mathrm{P}_{2} \mathrm{O}_{5} / \mathrm{Mg} \mathrm{TS}\right)$ [34]. Additionally, turkey manure and meat and bone meal exhibited a considerably higher $\mathrm{P}_{2} \mathrm{O}_{5}$ concentration of 12.6 and 156 . $8 \mathrm{~kg} \mathrm{P} \mathrm{O}_{5} / \mathrm{Mg}$ TS [34]. Regarding organic fertilizers of animal origin, it should be noted that there were restrictions in the European Ordinance 889/2008. Animal manure from intensive, non-ecological farming ("factory farming") is not allowed as fertilizer for organic farming systems. For meat and bone meal, an exclusion due to an evidence of chromium (VI) in milligrams per kilogram TS is intended. Also, the application of bone and meat meal is limited to the non-edible parts of the plants. The phosphorus concentration in the digestate of E. nuttallii regarding the total solid is consequently in a comparatively high range. With regard to this effect, this water plant is likely a good fertilizer.

Rock P fertilizers have a 9 to $26 \% \mathrm{P}_{2} \mathrm{O}_{5}$ significantly higher phosphorus content [35], but the finite nature of the worldwide P reserves should be taken into account. In addition, plant availability is a fundamental criterion. For the availability of $\mathrm{P}$ rock, a low $\mathrm{pH}$ value $(<6)$ is significant. A poor availability could, depending on the main crop, be only partially improved by suitable catch crops [36]. On the contrary, substrates for biogas became mineralized by anaerobic digestion, which resulted in a higher plant availability $[17,18]$.

By means of enrichment factors, the heavy metal concentrations in the digestate were also determined (Table 4). The legal limits applied in accordance with Annex 2 of Table 1.4 of the German Fertilizer Ordinance (German abbreviation: DüMV) are juxtaposed with heavy metal concentrations in Table 4. The German Fertilizer Ordinance defined the limits for the heavy metals arsenic, lead, cadmium, and nickel, which applies to raw materials and the final product. In the raw material (E. nuttallii total solid before anaerobic digestion), the legal limits of all heavy metals are to some degree well undercut. In digestate of $E$. nuttallii, the arsenic

Table 3 Calculation of the total phosphorus concentration in E. nuttallii digestate (TP $\left.\mathrm{DIG}_{\mathrm{G}}\right)$

\begin{tabular}{llllll}
\hline Year & & 2005 & 2006 & 2007 & 2008 \\
\hline $\mathrm{TP}_{\text {mean }}$ & {$[\mathrm{kg}$ P/Mg DM] } & 2.4 & 1.9 & 1.9 & 2.1 \\
$\mathrm{TP}_{\text {DIG }}$ & {$[\mathrm{kg}$ P/Mg DIG $]$} & 3.1 & 2.4 & 2.4 & 2.7 \\
\hline
\end{tabular}

Calculation using a non-rounded value; reference: UFZ. Mean total phosphorus concentration in E. nuttallii ( $\left.\mathrm{TP}_{\text {mean }}\right)$ quantity reached $33 \%$ and the lead quantity $3.3 \%$ of the legal limit. Hence, they were assessed as harmless. With 73.3\% exploitation, the concentration of cadmium in digestate was more critical. With an exploitation of 108 . $8 \%$, the nickel quantity was about $8.8 \%$ above the legal limit for fertilizers. As the compliance with legal limits for heavy metal concentrations is the absolute condition for the usage of digestates as fertilizers, the exploitation would be excluded in this case. The heavy metal concentrations from this study were not applied to every digestate of E. nuttallii, as the concentrations were not substrate-specific, but differed depending on location factors (especially the heavy metal contents of sediment and water bodies). The comparatively high nickel content in the sediment of the Lake Goitzsche was of geogene origin.

Zehnsdorf et al. [37] investigated the heavy metal contents in E. nuttallii in the river Parthe in Leipzig (Saxony, Germany) and identified that during 2 years, the nickel concentration in total solid never exceeded $40 \mathrm{mg} / \mathrm{kg}$ DM. The application of E. nuttallii digestate as a fertilizer in agriculture as a result was not fundamentally exclusionary. The respective special heavy metal concentrations (on a case-by-case basis) were rather decisively taken for legal admission. With the current study, the nickel (location-related) and cadmium concentrations were classified as potentially critical.

Table 4 PTE concentrations of the total solid and the total solid digestate compared to legal limits

\begin{tabular}{llll}
\hline PTE & $\begin{array}{l}\text { Concentration in TS } \\
\text { Unit }\end{array}$ & $\begin{array}{l}\text { Concentration in TS } \\
{[\mathrm{mg} / \mathrm{kg} \text { TS }]}\end{array}$ & $\begin{array}{l}\text { Legal limit } \\
{[\mathrm{mg} / \mathrm{kg} \text { TS }]}\end{array}$ \\
\hline As & 10.3 & 13.2 & 40.0 \\
$\mathrm{~Pb}$ & 3.9 & 5.0 & 150.0 \\
$\mathrm{Cd}$ & 0.85 & 1.1 & 1.5 \\
$\mathrm{Ni}$ & 68.0 & 87.0 & 80.0 \\
$\mathrm{Cr}$ & 11.9 & 15.2 & - \\
$\mathrm{Cu}$ & 16.1 & 20.6 & - \\
Zn & 154.5 & 197.8 & - \\
$\mathrm{TP}$ & 2032 & 2601 & - \\
\hline
\end{tabular}

Reference: UFZ. Total P (TP), PTE concentrations in the total solid of E. nuttallii (concentration in TS), concentration in total solids of digestate of $E$. nuttallii (concentration in $\mathrm{TS}_{\mathrm{DIG}}$ ), and the legal limits of heavy metal concentrations in fertilizers were given according to the German fertilizer ordinance (Annex 2, Table 1.4 DüMV) 
Table 5 Results of the calculation of fulfillment of $P$ demand for the years 2005 to 2008

\begin{tabular}{llllll}
\hline Year & & 2005 & 2006 & 2007 & 2008 \\
\hline $\mathrm{TP}_{\text {pot }}$ & {$[\mathrm{kg}]$} & 474.8 & 460.1 & 1666.7 & 586.1 \\
$\mathrm{TP}_{\text {pot,mean }}$ & {$[\mathrm{kg}]$} & 796.9 & & & \\
$\mathrm{P}_{\text {deficit }}$ & {$[\mathrm{kg} \mathrm{P} / \mathrm{ha}]$} & 7 & & & \\
$\mathrm{~A}_{\text {of }}$ & {$[\mathrm{ha}]$} & 67.8 & 65.7 & 238.1 & 83.7 \\
$\mathrm{~A}_{\text {of,mean }}$ & {$[\mathrm{ha}]$} & 113.8 & & & \\
$\mathrm{~A}_{\text {lake }} / \mathrm{A}_{\text {of }}$ & - & $20: 1$ & $20: 1$ & $6: 1$ & $16: 1$ \\
$\mathrm{~A}_{\text {littoral }} / \mathrm{A}_{\text {of }}$ & - & $6: 1$ & $6: 1$ & $2: 1$ & $5: 1$
\end{tabular}

References: UFZ, [28]. Total $\mathrm{P}$ recovery potential $\left(\mathrm{TP}_{\mathrm{pot}}\right)$, mean total $\mathrm{P}$ recovery potential $\left(\mathrm{TP}_{\text {pot,mean }}\right)$, mean $\mathrm{P}$ deficit of eight ecofarms in Saxony-Anhalt $\left(\mathrm{P}_{\text {deficit }}\right)$, area of fulfillment of $P$ demand $\left(A_{\text {of }}\right)$, mean of area of fulfillment of $P$ demand from 2005 to $2008\left(A_{\text {of,mean }}\right)$, lake area $\left(A_{\text {lake }}\right)$, littoral area $\left(A_{\text {littoral }}\right)$

In the course of other areas of research referring to $\mathrm{P}$, the recycling for nutrient recovery shown in numerous approaches is advisable. These procedures could also be applicable to digestates [38], but their implementation would have influence on the economic efficiency due to an increase of costs. A straightforward solution could be an admixture of biogas substrates with lower heavy metal contents, such as straw. The use of pure E. nuttallii substrates could be advisable due to their high water content, but was not practicable. A mixing with parts of straw to compensate for liquid loss is essential not only for silage but also for the use of E. nuttallii in biogas plants at all. As the addition of other substrates is necessary for usage, there is no contradiction of a possible mixing and dilution ban, such as might be created in the planned Ordinance of P Extraction (German abbreviation: AbfPhosV) [39].

The results of the extrapolation concerning Lake Goitzsche near Bitterfeld showed a fulfillment of demand of about 114 ha of agricultural land in organic farming by taking an average $\mathrm{P}$ demand of $7 \mathrm{~kg} \mathrm{P} /$ (ha*year) as a basis (Table 5). By December 2015, the share of organically cultivated land in Germany was (with 1,088,838 ha) about 6 . $5 \%$ of the total agricultural area [40]. The target of the German government was to increase organic cultivated land from $6.5 \%$ up to $20 \%$ [41].

German surface waters (lakes, rivers, canals, and close coastal waters) have a total area of 867,100 ha [42]. The total number of non-floating surface waters is currently unknown; according to a number of estimates, there are about 15,000 to 20,000 lakes with an area of over 1 ha.

Table 6 Phosphorus concentrations in the digestate of $E$. nuttallii in the years 2005 to 2008

\begin{tabular}{llllll}
\hline & & 2005 & 2006 & 2007 & 2008 \\
\hline $\mathrm{P}$ & {$[\mathrm{kg} / \mathrm{Mg} \mathrm{TS}]$} & 3.1 & 2.4 & 2.4 & 2.7 \\
$\mathrm{P}_{2} \mathrm{O}_{5}$ & {$[\mathrm{~kg} / \mathrm{Mg} \mathrm{TS}]$} & 7.1 & 5.5 & 5.5 & 6.2 \\
\hline
\end{tabular}

$P$ values were converted to the oxide form $\mathrm{P}_{2} \mathrm{O}_{5}$ by a conversion factor (of 2.2914)
The limnological database of the Brandenburg University of Technology (BTU) Cottbus-Senftenberg includes about 12,272 water bodies. In addition, German floating waters form a further potential with a total length of $130,000 \mathrm{~km}$ [43]. All those bodies of water also have a potential for $\mathrm{P}$ removal and an extraction of $\mathrm{P}$ resources through the anaerobic digestion of aquatic plants. The level of the potential depends on complex interactions (trophy, phytoplankton, etc.), which causes the growth and the absorption of environmental substances by water plants $[25,30,32]$.

With regard to the transferability of results to other water bodies and species of aquatic macrophytes, different $\mathrm{P}$ concentrations are to be expected. This verifies an analysis of aquatic macrophytes from Lake Tegel (Berlin, Germany) performed in 2015. The phosphorus content of $3.2 \mathrm{~kg} \mathrm{P} / \mathrm{Mg}$ DM of E. nuttallii from Lake Tegel was above the phosphorus content of $E$. nuttallii from Lake Goitzsche (Table 1). Lake Tegel had a significant eutrophication as a result of the longstanding use of sewage farms in North-West Berlin (Schönerlinde, Blankenfelde, Buch, Hobrechtsfelde). Since 1985, the P concentration caused by the inflow of Nordgraben and Tegeler Fließ has been reduced by an industrial-scale plant (German abbreviation: OWA) [44]. Nowadays, the nutrient status of the water bodies is mesotrophic [45], but the phosphorus content in sediment is still high (sediment samples from 2015 showed phosphorus contents between 0.647 and $1.280 \mathrm{~kg}$ P/Mg DM). Similarly, the additionally analyzed aquatic macrophytes Myriophyllum sp. and Callitriche sp. were found to have high (i.e., $3.0 \mathrm{~kg} \mathrm{P} / \mathrm{Mg} \mathrm{DM}$ ) or even higher (i.e., $4.5 \mathrm{~kg} \mathrm{P} / \mathrm{Mg}$ DM) phosphorus content, respectively. Due to different nutrient availability and further limnophysical factors, the developments of aquatic macrophytes' biomass also differ.

\section{Conclusions}

The growth of E. nuttallii biomass in Lake Goitzsche near Bitterfeld (Saxony-Anhalt, Germany) fluctuated during the investigation period (2005-2008) in the level and area of occurrence throughout the years. The analysis of phosphorus content, however, showed only small differences between $1.9 \mathrm{~kg} / \mathrm{Mg} \mathrm{DM}(2006,2007)$ and 2. $4 \mathrm{~kg} / \mathrm{Mg}$ DM (2005). Lake Goitzsche offered a recovery potential of $0.5 \mathrm{Mg}(2005,2006)$ to $1.7 \mathrm{Mg}$ (2007) phosphorus in the investigation period. This could meet the needs of 114 ha of agricultural land (ecofarm) on the basis of a mean demand amounting to $7 \mathrm{~kg} \mathrm{P} /($ ha"year).

Compared to other organic fertilizers, especially of plant origin, the digestate of $E$. nuttallii is very well suited as a fertilizer, not only due to the high phosphorus concentration and the improved plant availability but also due to mineralization during anaerobic digestion. As a recycling 
product, E. nuttallii digestate fertilizer would also preserve the worldwide P resources. Compliance with legal limits is mandated for usage in Germany. The nickel concentration of samples from 2011 was location-related above the legal limit and would impede the usage of this $E$. nuttallii digestate. This shows that site conditions for the quality of the biomass of aquatic plants are crucial. The usability of the digestate obtained from aquatic biomass as a fertilizer is therefore site-specific, especially with regard to the heavy metal concentrations, and the suitability must be assessed on a case-by-case basis. Though the analysis of 2011 elucidated the need for heavy metal verification in digestates, the sole anaerobic digestion of pure $E$. nuttallii substrate is unsuitable for practice for different reasons. A common anaerobic digestion with straw could also reduce the heavy metal concentrations in the digestate.

The results of this study showed the fundamental potential of phosphorus recovery through anaerobic digestion of aquatic macrophytes. For the more detailed recording of the potential of recycling phosphorus from aquatic freshwater plants and, in particular, of aquatic macrophytes in Germany, further investigation of the surface waters (regarding the littoral area) is required. Due to the annual fluctuations of biomass growth and phosphorus contents, investigations over longer periods are necessary. For a euthrophication assessment and management, the evaluation of the $\mathrm{P}$ in aquatic macrophytes derived from water bodies or sediment, which is differing in diverse water bodies, might become important. A well-founded assessment of the phosphorus potential in aquatic plants (regarding recycling and euthrophication aspects) is crucial for sustainability judgment.

\section{Additional file}

Additional file 1: Data base, calculations and extrapolation of $\mathrm{P}$ recovery potential, PTEs and Enrichment of Elodea nuttallii. (PDF 277 kb)

\footnotetext{
Abbreviations

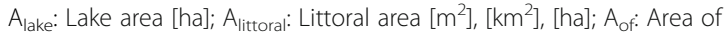

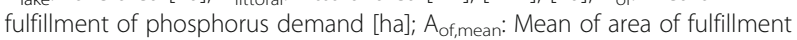
of phosphorus demand from 2005 to 2008 [ha]; EF: Enrichment factor [-]; FM: Fresh matter [g]; $\mathrm{m}_{\mathrm{A}}$ : Mass of ash [g]; $\mathrm{m}_{\mathrm{H}_{2} \mathrm{O}}$ : Mass of water [g]; $\mathrm{m}_{\mathrm{Ts}}$ : Mass of total solid before anaerobic digestion [g]; $\mathrm{m}_{\mathrm{vs}}$ : Mass of total volatile solid [g]; $P_{\text {deficit: }}$ Mean P deficit of eight ecofarms in Saxony-Anhalt [kg P/(ha*year)]; PTEs: Potentially toxic elements [-]; q: Net average of specific gas production $\left[\mathrm{m} / \mathrm{N} / \mathrm{gvs}_{\mathrm{vS}}\right]_{;} \mathrm{TP}_{\mathrm{DIG}}$ : Total P concentration in digestate of E. nuttallii $[\mathrm{kg} \mathrm{P} / \mathrm{Mg}$ $\mathrm{DIG}] ; \mathrm{TP}_{\max }$ value: Maximum of total $\mathrm{P}$ concentration in E. nuttallii $[\mathrm{kg} \mathrm{P} / \mathrm{Mg}$ TS]; TP mean: Mean total P concentration in E. nuttallii $[\mathrm{kg} \mathrm{P/Mg} \mathrm{TS}] ; \mathrm{TP}_{\min }$ value: Minimum of total $P$ concentration in E. nuttallii $[\mathrm{kg} P / \mathrm{Mg} \mathrm{TS}]$; TP pot: Total phosphorus recovery potential $[\mathrm{kg}],[\mathrm{Mg}] ; \mathrm{TP}_{\text {pot,mean: Mean total }}$ phosphorus recovery potential [kg]; TS\%: Percentage of total solid referred to

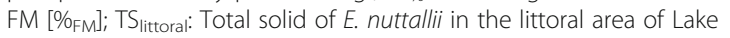
Goitzsche [g], [Mg]; TS max value: Maximum of total solid of E. nuttallii [Mg TS/ $\left.\mathrm{km}^{2}\right],\left[\mathrm{g} \mathrm{TS} / \mathrm{m}^{2}\right]$; TS mean: Mean total solid of E. nuttallii $\left[\mathrm{Mg} \mathrm{TS} / \mathrm{km}^{2}\right]\left[\mathrm{g} \mathrm{TS} / \mathrm{m}^{2}\right]$; $\mathrm{TS}_{\min }$ value: Minimum of total solid of $E$. nuttallii $\left[\mathrm{Mg} \mathrm{TS} / \mathrm{km}^{2}\right],\left[\mathrm{g} \mathrm{TS} / \mathrm{m}^{2}\right]$; $V_{\%}$ : Percentage of volatile solid referred to TS\% $\left[\% \%_{S}\right] ; W_{C H 4}$ : Percentage of the mean mass fraction of $\mathrm{CH}_{4}$ in biogas [\%]
}

\section{Acknowledgements}

This project was funded by the German Federal Ministry of Food and Agriculture based on a decision of the German Bundestag with funds from the "Energy and Climate Fund" investment fund (grant number 22403013). The authors would like to thank Bärbel Haase, Susann Hoffmann, Martin Apelt, and Marcel Schneider for their assistance in conducting the experiments and Hans-Joachim Stärk for analyzing the E. nuttallii samples regarding the elements. Our thanks equally go to the divers group consisting of Karsten Rahn, Martin Wieprecht, Michael Herzog, and Michael Beyer, who harvested the macrophytes' biomass between 2004 and 2008. In addition, we would also like to thank Ines Merbach and her laboratory assistants in Bad Lauchstädt (Saxony-Anhalt, Germany) for their valuable support in preparing macrophytes' biomass.

\section{Funding}

The investigations forming the basis for this article were carried out within the framework of the "Aquatic macrophytes - Optimal ecological and economic use" (AquaMak) research project. The "AquaMak" project is supported by the German Federal Ministry of Food, Agriculture and Consumer Protection with funds from the Energy and Climate Funds (EKF) on the basis of a decision of the German Parliament (grant number: 22403013). The project partners are the Helmholtz Centre for Environmental Research - UFZ, the Nürtingen-Geislingen University - HFWU, and the German Biomass Research Centre - DBFZ.

The investigations at Lake Goitzsche between 2004 and 2008, carried out by the Department of Lake Research, Helmholtz Centre for Environmental Research, Magdeburg, Germany, were financed by Lausitzer und Mitteldeutsche Bergbau-Verwaltungsgesellschaft (LMBV).

\section{Availability of data and materials}

The datasets supporting the conclusions of this article are given in Additional file 1.

\section{Authors' contributions}

NS performed the study for the article, collected and sorted the publications and the information material, applied the dataset for calculations, executed the extrapolation, and prepared the manuscript. HR led the investigation of E. nuttallii biomass between 2004 and 2008 and collected and analyzed the samples. HW was responsible for the batch tests and ensiling experiments and collected and analyzed the samples. AZ and LM contributed to the consultations and critical reading of the manuscript. WS provided the idea for the study and supervised it supported by BI. All authors edited and approved the final manuscript.

\section{Ethics approval and consent to participate}

Not applicable.

\section{Consent for publication}

Not applicable.

\section{Competing interests}

The authors declare that they have no competing interests.

\section{Publisher's Note}

Springer Nature remains neutral with regard to jurisdictional claims in published maps and institutional affiliations.

\footnotetext{
Author details

${ }^{1}$ Department of Biochemical Conversion, German Biomass Research Centre gGmbH, Torgauer Straße 116, 04307 Leipzig, Germany. ${ }^{2}$ Faculty of Natural Sciences III, Martin Luther University Halle-Wittenberg, Von-Seckendorff-Platz 3, 06120 Halle, Germany. ${ }^{3}$ Department of Environmental Biotechnology, Helmholtz Centre for Environmental Research, Permoserstrasse 15, 04318 Leipzig, Germany. ${ }^{4}$ Department of Lake Research, Helmholtz Centre for Environmental Research, Brueckstrasse 3a, 39114 Magdeburg, Germany. ${ }^{5}$ Department Civil Law and Public Law with References to the Law of Europe and the Environment, Brandenburg University of Technology (BTU) Cottbus Senftenberg, Platz der Deutschen Einheit 1, 03046 Cottbus, Germany.
} 


\section{Received: 29 August 2017 Accepted: 26 March 2018}

\section{Published online: 01 May 2018}

\section{References}

1. Kolbe H (2013) Particularities of phosphorus supply in organic locations in Erzgebirge and Vogtland. [Besonderheiten der Phosphorversorgung von ökologisch bewirtschafteten Standorten im Erzgebirge und Vogtland.] Paper presented at Gäa- und Naturland-Ackerbauseminar, Agrargenossenschaft Oberes Vogtland, D-Adorf, 08. Aug 2013.

2. Voß A (2007) Investigation and modelling of nitrogen and phosphorus sales and transport processes in meso-scale catchment areas of lowland through the example of Nuthe, Hammerfliess and Strepenitz. [Untersuchung und Modellierung der Stickstoff- und Phosphorumsatz- und Transportprozesse in mesoskaligen Einzugsgebieten des Tieflandes am Beispiel von Nuthe, Hammerfließ und Stepenitz.] Dissertation, University of Potsdam.

3. Cordell D, Drangert J-O, White S (2009) The story of phosphorus: global food security and food for thought. Glob Environ Chang 19:292-305. https://doi.org/10.1016/j.gloenvcha.2008.10.009.

4. Dawson CJ, Hilton J (2011) Fertiliser availability in a resource-limited world: production and recycling of nitrogen and phosphorus. Food Policy 36:S14S22. https://doi.org/10.1016/j.foodpol.2010.11.012..

5. Schröder J J, Cordell D, Smit A L, Rosemarin A (2010) Sustainable use of phosphorus. Plant Research International report no.357, Universität Wageningen und Stockholm Environment Institute, Wageningen.

6. Vaccari DA, Strigul N (2011) Extrapolating phosphorus production to estimate resource reserves. Chemosphere 84:792-797. https://doi.org/10 1016/j.chemosphere.2011.01.052.

7. Van Norden O H (2015) Development of a system for quantification of criticality of industrial minerals and special consideration of phosphate. [Entwicklung einer Systematik zur Quantifizierung der Kritikalität von Industriemineralen und besonderer Berücksichtigung von Phosphat.] Dissertation, RWTH Aachen University.

8. Barrat-Segretain M-H, Cellot B (2007) Response of invasive macrophyte species to drawdown: the case of Elodea sp. Aquat Bot 87:255-261.

9. Huotari T (2012) Population genetic structure and phylogeography of invasive aquatic weed, Elodea canadensis (Hydrocharitaceae) and comparative analyses with E. nuttallii. Academic dissertation. University of Helsinki.

10. Di Nino F, Thiébaut G, Muller S (2005) Response of Elodea nuttallii (Planch.) H. St. John to manual harvesting in the north-east of France. Hydrobiologia 551:147-157.

11. Hérault B, Bornet A, Trémolieres M (2008) Redundancy and niche differentiation among the European invasive Elodea species. Biol Invasions 10:1099-1107.

12. Cook CD, Urmi-König K (1985) A revision of the genus Elodea (Hydrocharitaceae). Aquat Bot 21(2):111-156

13. Scherer L, Pfister S (2015) Modelling spatially explicit impacts from phosphorus emissions in agriculture. Int J Life Cycle Assess 20:785-795. https://doi.org/10.1007/s11367-015-0880-0.

14. Zehnsdorf A, Hussner A, Eismann F, Rönicke H, Melzer A (2015) Management options of invasive Elodea nuttallii and Elodea canadensis. Limnologica 51:110-117. https://doi.org/10.1016/j.limno.2014.12.010.

15. Zerbe S, Wiegleb V (2008) Renaturation of ecosystems in Central Europe. [Renaturierung von Ökosystemen in Mitteleuropa.] Spektrum, p 496.

16. Fachagentur Nachwachsende Rohstoffe, FNR (no year) Water plants—raw material for biogas plants? [Wasserpflanzen - Rohstoff für Biogasanlagen?] http:// biogas.fnr.de/projekte/biogassubstrate/wasserpflanzen/. Accessed 21 Sept 2016.

17. Gallegos D, Wedwitschka H, Moeller L, Weinrich S, Zehnsdorf A, Nelles M, Stinner W (2018) Mixed silage of Elodea and wheat straw as substrate for energy production in anaerobic digestion plants. Energy Sustain Soc 8:7. https://doi.org/10.1186/s13705-018-0148-1.

18. Grieb B, Hofmann F, Blumenstein B (2015) Fertile ground even in organic farming without animals. [Fruchtbarer Boden auch im viehlosen Biolandbau. ] Ökologie und Landbau, pp 34-36.

19. Lichti F H (2013) Valuation and optimisation of nutrient and environmental impact by digestates from biogas production [Bewertung und Optimierung der Nährstoff- und Umweltwirkung von Gärrückständen aus der Biogasgewinnung.] Dissertation, Technical University of Munich.

20. Rönicke H (2008) Seasonal trends and nutrient supply of submersing macrophytes in the mining lake Goitzsche. [Jahreszeitliche Entwicklung und Nährstoffversorgung submerser Makrophyten im Tagebausee Goitzsche.] http://www.anhalt-bitterfeld.de/media/pdf/amt80/roennicke-magdeburg pdf. Accessed 18 Sept 2016.
21. Lausitzer und Mitteldeutsche Bergbau-Verwaltungsgesellschaft, LMBV (2009) Redevelopment area Goitzsche-from surface mining to landscape park. [Sanierungsgebiet Goitzsche - vom Tagebau zum Landschaftspark.] https:// www.Imbv.de/index.php/Publ_Mitteldeutschland.html?file=files/LMBV/ Publikationen/Publikationen\%20Mitteldeutschland/Allgemein\%20MD/LMBV_ 60JahreGoitzsche_2009.pdf. Accessed 08 Sept 2016.

22. LMBV (2011) Landscapes in transformation-post-mining lake in Central Germany. [Landschaften im Wandel - Bergbaufolgesee in Mitteldeutschland.] https://www.Imbv.de/index.php/Publ_Mitteldeutschland.html?file=files/LMBV/ Publikationen/Publikationen\%20Mitteldeutschland/Allgemein\%20MD/LMBV_ 60JahreGoitzsche_2009.pdf. Accessed 08 Sept 2016.

23. Rönicke H, Angelstein S, Schultze M, Geller W (2005) Invasion of submersing macrophytes in the mining lake Goitzsche. [Invasion submerser Makrophyten im Tagebausee Goitsche.]. In: DGL und Deutschsprachige Sektion der Societas Internationalis Limnologiae (SIL) (ed.) Tagungsbericht 2005 (Karlsruhe). DGL, Werder, pp 139-143.

24. Rönicke H, Beck B, Schultze M, Beyer M, Angelstein S (2007) Growth dynamic of Elodea nuttallii in the mining lake Goitzsche. [Wachstumsdynamik von Elodea nuttallii im Tagebausee Goitsche.] Paper presented at Jahrestagung der Deutschen Gesellschaft für Limnologie (DGL) und der deutschen und österreichischen Sektion der Societas Internationalis Limnologiae (SIL), Dresden, 25.-29 Sept 2006.

25. Rönicke $H$, Büttner $O$, Schultze $M$, Herzsprung P (2008) Abundance dynamic and intern nutrient supply of littoral stock of submersing macrophytes in the mining lake Goitzsche. [Abundanzdynamik und interne Nährstoffversorgung der Litoralbestände submerser Makrophyten im Tagebausee Goitsche.]. In: DGL und Deutschsprachige Sektion der Societas Internationalis Limnologiae (SIL) (ed.) Erweiterte Zusammenfassungen der Jahrestagung 2008 (Konstanz), pp 193-198.

26. Weißbach F, Strubelt C (2008) Correcting the dry matter content of maize silages as a substrate for biogas production. Landtechnik (Agric Eng) 63:82-83.

27. VDI 4630 (2016) Fermentation of organic materials - characterization of the substrate, sampling, collection of material data, fermentation tests, 2016th edn. Beuth Verlag, Berlin.

28. Harzer N (2006) Humus and nutrient balance of organic farms and system tests in the federal state Saxony-Anhalt. [Humus- und Nährstoffhaushalt ökologischer Betriebe und Systemversuche im Land Sachsen-Anhalt.] Diploma Thesis, Martin Luther University Halle-Wittenberg.

29. Döhler H, Wulf S, Grebe S, Roth U, Klages S, Amon T (2010) Quality and use of digestate. Guideline biogas - from production to end use. [Qualität und Verwertung des Gärrestes. Leitfaden Biogas - Von der Gewinnung bis zur Nutzung.]. FNR, Gülzow-Prüzen, pp 211-232.

30. Angelstein S, Schubert H (2008) Elodea nuttallii: uptake, translocation and release of phosphorus. Aquat Biol 3:209-216. https://doi.org/10.3354/ab00080.

31. Angelstein S, Wolfram C, Rahn K, Kiwel U, Frimel S, Merbach I, Schubert H (2009) The influence of different sediment nutrient contents on growth and competition of Elodea nuttallii and Myriophyllum spicatum in nutrient-poor waters. Fundam Appl Limnol/Archiv für Hydrobiologie 175(1):49-57. https:// doi.org/10.1127/1863-9135/2009/0175-0049.

32. Stengert M, Podraza P, van de Weyer K (2008) The development of Elodea nuttallii (PLANCH.) ST. JOHN in the artificial lakes of lake Ruhr by influence of flood incidents in spring 2006 or summer 2007. [Die Entwicklung von Elodea nuttallii (PLANCH.) ST. JOHN in den Ruhrstauseen unter dem Einfluss von Hochwasserereignissen im Frühjahr 2006 bzw. Sommer 2007.] In: DGL (ed.) Erweiterte Zusammenfassung der Jahrestagung 2007 (Münster), Werder.

33. Landwirtschaftliche Untersuchungs- und Forschungsanstalt, LUFA (no year) Conversion factors of nutrients. [Umrechnungsfaktoren für Nährstoffe von der Elementform in die Oxidform und umgekehrt.] https://www.lufa-nord-west.de/ index.cfm/action/downloadcenter?file=0FE6CD. Accessed 23 Sept 2016.

34. Bayerische Landesanstalt für Landwirtschaft, Lfl (no year) Tabelle 7: Nutrient contents of organic fertilizers when they are applied. [Nährstoffgehalte organischer Dünger zum Zeitpunkt der Ausbringung.] http://www.Ifl.bayern. de/mam/cms07/iab/dateien/basisdaten_2013_7.pdf. Accessed 23 Sept 2016.

35. Forschungsinstitut für biologischen Landbau, FiBL (2010) List of auxiliary material 2010. List of auxiliary material for organic farming. [Betriebsmittelliste 2010. Hilfsstoffliste für den biologischen Landbau.] http:// www.betriebsmittelliste.ch/fileadmin/documents/de/hifu/archiv/ betriebsmittelliste_2010.pdf. Accessed 10 Sept 2016.

36. Steffens D, Stamm R, Leithold G, Schubert S (2003) Phosphate mobilization by main and catch crops after fertilization with soft ground rock phosphate 
in organic agriculture. [Phosphat-Mobilisierung durch Haupt- und Zwischenfrüchte nach Düngung von weicherdigem Rohphosphat im ökologischen Landbau.] http://orgprints.org/17240/1/17240-02OE424-uni_ giessen-steffens-2003-phosphatmobilisierung.pdf. Accessed 10 Sept 2015.

37. Zehnsdorf A, Moeller L, Stärk H-J, Auge H, Röhl M, Stinner W (2017) The study of the variability of biomass from plants of the Elodea genus from a river in Germany over a period of two hydrological years for investigating their suitability for biogas production. Energy Sustain Soc 7:15. https://doi. org/10.1186/s13705-017-0117-0.

38. Frank D (2013) Experimental study and modeling of the precipitation of potassium-magnesium-phosphate. [Experimentelle Untersuchung und Modellierung der Fällung von Kalium-Magnesium-Phosphat.] Dissertation, University of Stuttgart.

39. Bergs C-G (2015) Phosphorus - where the journey will go to? Goals and concepts of the policy. [Phosphor - wo geht die Reise hin? Ziele und Vorstellungen der Politik.] https://www.dwa-st.de/files/_media/content/ PDFs/LV_ST/serv/rueck/lvt/4_2_Bergs_Politik.pdf. Accessed 21 July 2017.

40. Bundesanstalt für Landwirtschaft und Ernährung, BLE (2015) Structural data of organic agriculture for 2015. [Strukturdaten zum ökologischen Landbau für das Jahr 2015.] https://www.ble.de/SharedDocs/Downloads/DE/ Landwirtschaft/Oekologischer-Landbau/ZahlenOekolandbau2016.pdf? blob=publicationFile\&v=3. Accessed 08 Sept 2016

41. Umweltbundesamt (2015a) Environmental benefits of organic farming [Umweltleistungen des Ökolandbaus.] http://www.umweltbundesamt.de/ themen/boden-landwirtschaft/landwirtschaft-umweltfreundlich-gestalten/ oekolandbau. Accessed 08 Sept 2016

42. Statistisches Bundesamt (2013) Land- und Forstwirtschaft, Fischerei. Ground area by type of actual use. [Bodenfläche nach Art der tatsächlichen Nutzung.] Fachserie 3 Reihe 5.1. https://www.destatis.de/DE/Publikationen/ Thematisch/LandForstwirtschaft/Flaechennutzung/ Bodenflaechennutzung2030510167004.pdf?_blob=publicationFile. Accessed 16 Sept 2016

43. Umweltbundesamt (2015b) Ecological status of running waters [Ökologischer Zustand der Fließgewässer.] http://www.umweltbundesamt. de/daten/gewaesserbelastung/fliessgewaesser/oekologischer-zustand-derfliessgewaesser. Accessed 09 Sept 2015.

44. Schauser I, Chorus I (2009) Water and phosphorus mass balance of Lake Tegel an Schlachtensee-a modelling approach. Water Res 43(6):1788-1800. https://doi.org/10.1016/i.watres.2009.01.007.

45. Hoffmann A, Gunkel G (2011) Bank filtration in the sandy littoral zone of Lake Tegel (Berlin): structure and dynamics of the biological active filter zone and clogging processes. Limnologica 41:10-19. https://doi.org/10. 1016/j.limno.2009.12.003.

\section{Submit your manuscript to a SpringerOpen ${ }^{\circ}$ journal and benefit from:}

- Convenient online submission

- Rigorous peer review

- Open access: articles freely available online

- High visibility within the field

Retaining the copyright to your article 